\title{
ABL1 Gene Mutation
}

National Cancer Institute

\section{Source}

National Cancer Institute. ABL1 Gene Mutation. NCI Thesaurus. Code C153100.

A change in the nucleotide sequence of the ABL1 gene. 